\title{
The Strengthening of Students' Empathy through Living History
}

\author{
Dewicca Fatma Nadilla ${ }^{1}$, Sariyatun ${ }^{1}$, Sunardi ${ }^{1}$ \\ ${ }^{1}$ Sebelas Maret University Surakarta
}

\begin{abstract}
History education in the curriculum of 2013 has a dominant role to shape the character of the nation. One of the roles of learning history is to awaken and maintain the spirit of nationalism that can be achieved by understanding the past in the context of the present. Therefore, it takes a model of historical learning that can be used as the facility of students to actively participate in understanding past events in order to shape the history of students in the past. Living History is a concept of learning that present a lively atmosphere in class by presenting the reactor of the past. Living history model is one of the learning ways which is the implementation of the research steps history. Living History can also be used to analyze historical events that occur around the environment where learners live and also used in an effort to perform the deconstruction of local values that developed in society. Through the use of living history students can be guided to build the mind constructs and perceptions of past figures in historical events. The main purpose of these activities is as an effort to improve students' historical empathy through observation activities and deconstruction of living values that flourish in the community. This study used a qualitative approach with data collection methods using literature study by collecting relevant sources in the form of books and research journals, then to see the problems and needs of students was done with observation and interviews to several schools in Tabalong Regency. The application of living history to strengthen historical empathy is an innovation in historical learning based on needs analysis and problems that occurred in Tabalong, South Kalimantan.
\end{abstract}

\section{Keywords: History Learning, Empathy History, Living History}

\section{INTRODUCTION}

Indonesia is at the point of emergency, this is conveyed by the former minister of Education Anies Baswedan in 2014 in his paper. It is explained then in the various factors one of which is about the moral decline that continues to undermine the heart of the Indonesian nation, undeniably this is also one of the bad impacts from globalization that not only brings a variety of practicality but also presents a world without boundaries that can be accessed by anyone and anytime. Access information that very easy to reach by various circles no exception learners brings problems in the future. As is strongly felt, no wonder, not surprisingly if it affects the psychological development of children. The perceived influence is not only seen in the attitudes and habits displayed by the child every day, but also more extreme ends up in criminal acts committed by school-aged children. This is supported by data 
held by KPAIs during 2016 at least 44,571 cases nationwide, of which 617 cases occurred in South Kalimantan which ended with 93 children ending up in rehabilitation or juvenile prisons (KPAI: 2017).

The implementation of the 2013 curriculum is aimed at shaping the character of students in accordance with the Indonesian identity which is very multicultural with 18 values of characters developed both in the process of learning directly to the school culture that is run. History education that received extraordinary attention in the application of Curriculum 2013 in Indonesia certainly not apart from the problems faced by the nation today, where the symptoms of mushrooming intolerance can easily be encountered in both the real world and the virtual world. This can be directly seen from the various cases occurring in Indonesia where intergroup disputes end up clashing, the emergence of provocation accounts, disparaging views of an ethnic and class, and shaken state motto due to an issue. Another very worrying case is the lack of respect for the heroes by the young generation who have fought in the defense of the country. Several cases had burst the viral is an insult to Pancasila as a symbol of the state of Indonesia, humiliation by occupying the statue of the Head of Hero by unscrupulous students, making fun of the hero's face, and marking some heroes with a word full of sara.

Based on the above case explanation certainly strengthen the speculation of the situation of the young generation of Indonesia who have moral degradation and antipathy to the history of the country. Because of these things, it can be analyzed several factors that cause the origin of external factors learners and internal learners in the context of learning received in the school. One of the factors why that thing happens is the concern of learning history that continues to be regarded as a less important and boring subjects for learners. Therefore, an innovation in historical learning is needed at least to be tried by historical educators to build a fun, active, and meaningful history lesson in accordance with the great design of the learning of curriculum history 2013 by reinforcing the history of learners through the implementation of living history in learning

Living History is a learning model based on constructivist paradigm in accordance with the guidelines in the 2013 curriculum. The use of living history based on the concept can be used as a strengthening of the history of learners, according to previous research conducted by Sarah Brooks (2008) that empathy history can be strengthened through active learners' experience in historical learning by observing the source of history directly. The same thing is explained by Endacott and Sturtz (2011) which states that the historical empathy of data is constructed through analyzing the relationship between past events and current events, so bringing history directly to students is an effective way to reinforce the historical empathy [2].

\section{RESEARCH METHOD}

This study uses a qualitative approach which according to Moleong (2014) Qualitative research is a study that aims to understand the phenomenon of what is experienced by the subject of research such as behavior, perception, motivation, action, and so on thoroughly by way of describing it in the form of words and language, in a natural, natural context with the use of natural methods [3]. So the type of research 
conducted is a descriptive-qualitative research based on observations on historical learning process at SMA Negeri in Tabalong Regency, South Kalimantan. The technique of data collection are conducted in accordance with the qualitative principle that is through direct observation in order to see the process of learning history at at least three SMA Negeri in Tabupong District, in order to strengthen the results of observations and then conducted in-depth interviews of teachers of history subjects as many as 5 (five) Representing the learning process at school and 6 (six) students representing each school. Furthermore, the last document study conducted by collecting relevant sources related to the title that was raised in the form of books, scientific research journals, and articles related to the research title namely "Empowering the History of Learners through Living History in History Learning".

\section{DISCUSSION}

\section{Learning Problems at Senior High School in Tabalong District}

Aman's historical learning (2011: 2) has a fundamental task to raise awareness of empathy and tolerance among learners accompanied by mental and social abilities to develop creative, innovative, and participative imaginations and attitudes, Aman further mentions at least four learning functions of history are: (1) to arouse interest in the history of his homeland. (2) to gain inspiration from his history, both stories of heroism, both events that are a national tragedy. (3) to provide a rational, critical, and empirical way of thinking, (4) to develop an attitude of respect for human values. History learning has a very real role where it is based on two important things in the pillar of education that is to serve as learning includes all the processes from planning to evaluation, in the context of cognitive development, and the second element of moral education that includes the moral life of the nation, the guidance of good citizens, democratic, and responsible attitude as a form of historical awareness of the future of the nation. Moral education in the study of history itself cannot be separated from the values of humanism that is very concerned about the norms (Gottschalk, 1973: 10). Through learning history learners are expected to have a strong personality that is in accordance with the identity of the nation and its identity.

Implementation of the 2013 curriculum is certainly based on the urgency related to the situation of Indonesia's young generation today. The impact of globalization that continues to stem the mental of the young generation certainly cannot be fully blamed because the global influence also bring much positive impact for Indonesia, especially in the progress of science and technology. Providing a real positive impact is also not separated from the negative impact that shadows it, this can be explained from various data showing the moral degradation of Indonesia's young generation, both in big cities and small towns. Therefore, it is summarized in the design of the 2013 curriculum that we also know as a characteristic curriculum offers a package in which direct conceptualized of 18 characters that should be developed by learners as well as the scientific ability of learners who are encouraged by technology development.

Highlighting the subject on the implementation of history subjects highlighted as the subjects of values shaping the character of the nation, which has implications directly on the increase of learning hours of history in high school and vocational high school. Therefore, the paradigm shift occurs in the learning of history in the curriculum 
2013 in the form of competency based curriculum, So that with the change of this paradigm it is hoped that historical learning will not only focus on facts and historical events but more than that it can have direct implications on the stage of historical thinking, historical skills, the usefulness of historical learning and the exploration of values in historical events as a reflective form thinking educate learner [6]. .

Aims to shape the character and national identity to make learning in curriculum 2013 gives space on the connectedness of local history materials with a national history that aims to instill a sense of national love because of its environment in this area has a great contribution in the national history of Indonesia. This approach became one of the innovations in historical learning based on reality, this statement was written Hassan (2015: 8) which unraveled as follows: 1) The history of national and regional history mutually support one another; 2) historical events that occur in the region cannot be separated from what happens at the national level; 3) the understanding of regional historical events and their characters will help provide a more profound and meaningful understanding of historical events at the national level; 4) understanding the relevance of regional and national events to provide students' understanding and awareness of regional contributions in enriching national culture and strengthening national unity; 5) an understanding of the interrelationship of historical events in the region and nationally builds awareness and understanding of the identity of the nation. 6) Strengthening the collective understanding of memory as a nation; 7) studying the linkages between national and regional events at the national level and providing awareness of historical events at the national level [6].

Based on the explanation above, it is clear that the purpose of learning history is not only based on cognitive point but also broader emphasis on affective aspects with the development of values and character of students, as well as psychomotor aspects related to historical learning skills that must also be owned by students. The design of history learning and the objectives set forth above can be a reference in the implementation of learning history. As it has been known that the expectations have been lit up so in the implementation of the field must have some problems that actually become a classical stereotype attached to the learning of history.

Looking from the point of view of the students then there are several points of problems that can be used as a reflection of the implementation of learning history so far. The opinions expressed by students related to the learning of history that has a great influence on student interest where there are still many students who consider history is a boring learning and only contains repetition materials, so it is not surprising if often found students who skipped during the course of history. One of the important factors of low interest of students will learn history is due to the lack of involvement of learners directly on the learning process. This opinion is even similar to proposed by Subakti (2015: 3) that the trend of educators of history using this conventional method which became one of the reasons why the history of learning is labeled as learning boring. Conventional methods themselves are in their consciousness cannot give direct touch to the emotional students which has implications on the achievement of learning objectives.

In fact historical learning that has been designed in such a way in the national curriculum of Indonesia still has problems in its application. As for the problem in question that learners tend to regard history as an easy subject so that learners only to the stage of understanding the material alone without deepening what the meaning is in every event. Based on the preliminary observations made at the state high schools in 
Tabalong Regency there are some classic problems that continue to haunt historical learning:

1) Teachers who still use the lecture method and still use the teacher center approach so that history learning is considered boring, this is because in this semester is the beginning of the implementation of the 2013 curriculum simultaneously, so that many teachers are still not mastered techniques and learning strategies. 2) The use of learning models that are less precise and not in accordance with the context of the material so it has not been able to touch values / meanings contained in every historical event. 3) The subject of history is still regarded as a subject without meaning because it tells about the past by the students. 4) Unable to integrate local knowledge and local history in its learning. 5) Historical learning has not been based on the formation of value, especially the value of the localization. 6) Unavailability of learning resources that can become a motor of national and local history around the environment of learners. 7) Direct involvement of students in the learning process is very rare.

As has been explained in the design of curriculum development 2013, it is needed an integration of local history in history lessons in schooling to shape the attitudes and identity of learners. The local history and cultural wisdom of each region are different, this difference which then builds a teak self or the character of the community. The values contained in both local history and local wisdom are expected to be well integrated in a learning system especially history learning as a scientific study. The formation of the character cannot be released later than the influence of the environment in which each region has a unique characteristic that is not equal to each other's, the advantages are then illustrated in the behavior displayed in everyday life.

\section{Historical Empathy}

The word empathy originally derived from the word Einfuhlung used by the German philosophers in the 19th century which is translated with the word empathy. The philosopher Robert Vischer uses this term to describe the pleasure experienced when we contemplate a work of art. Where the word is represented as a projection of self and feeling into a painting even the beauty of nature [7]. In the Greek language empathy is derived from the word empathia which means entering the feelings of others or sharing feelings of one's desires or sadness. If we want to understand people and their situations rather than simply explaining it requires an interpretation and struggle for meaning.

A deeper realization of the concept of empathy will then refer to the emotional content of an experience that provides tremendous energy. Empathy alone is an impulse more than based on rational thinking in which the immediate impulse is formed to recognize the feelings of others physically, simplicity of bodily empathy. Based on these descriptions, empathy can be the result of thoughts and feelings consisting of affective responses, and cognitive responses, feeling what others feel and understanding why others feel it.

Empathy History is a process that involves affective and cognitive components using the life experiences of historical figures as a medium of contextualization and understanding of the meaning of historical events. For now, much of the literature on historical empathy is primarily focused on ensuring the role of historical empathy in achieving the curricular goals relating to subject matter and historical skills. Empathic history then emphasizes on the formation of values and meanings constructed through 
the cognitive reconstruction of students derived from the process of understanding and analysis of historical events so that by making the history of empathy as a goal in the learning of history will have an explicit impact on the real condition of students in the attitude of the community. Moreover, according to historically empathic experts can be used to hone the potential of learners to promote complex ideas, moral judgments, and the dispositional appreciation of the complexity of the situation faced by people in the past. So in short the history of empathy can also be used as a bridge to build social empathy students in the community.

One way to improve the history of empathy in the context of education and learning in schools is the formation of learners' experiences actively engaged in historical learning [8], whereas Sarah in his research brings learners to the experience of direct observation of historical sources then explored simply by considering the value and meaning embodied in historical events. This is in line with the statement put forward by Jill Jensen (2011: 4) which states that the history of empathy itself can be built through a visualization of historical events that can also be assisted by documentary video playback or historical documents related to the events discussed in historical learning [9].

The empathy of history is included in the category of perspective taking which is an important skill for students to learn. Quoting the opinion of Pieter Seixas (1996) that historical empathy implies an understanding that "the people of the past must have historical empathy to understand the complexity of how historians explain past events. As historical empathy, defined by Downey [9] is an ability to recognize how the past is different from now, to distinguish between perspectives from the past, to explain the author's point of view, and to maintain. In simple terms, historical empathy can be interpreted as an attitude based on the construct of our minds about past events, by looking at the present situation, and wisely relate it to the past. In addition empathy history has three important elements of the forming of the ability of identification that is influenced by understanding historical events, imagination to connect past events and draw meaning to contemporary events.

Based on the explanation above, it is important to build the historical empathy that is useful for preparing students to be good citizens because the history of empathy has an important point that includes the absorption of values and application of attitudes as a real impact of the realization of the goal of history learning in the form of historical empathy. The only example is the history of empathy teaches students to be able to appreciate the various perceptions in which differences in perception are part of a social interaction. Some experts then argue that historical empathy is basically a level of historical understanding that is not easy to achieve, but to grow it can be done by providing stimulus cognitive and affective applications. The improvisation that can be done by teachers to realize the empathy of student history is by applying the strategy of learning history that precisely include source, model, and method of learning history. Historical empathy becomes an important goal to be achieved as a result of historical learning. In order to realize this requires a good cooperation of teachers and learners, where to achieve an empathy of history requires proper mastery and instructional by the teacher so that the goals can be achieved by students [10]. 


\section{Living History in Historical Learning}

Learning that involves the experience and active participation of students is one of the options that can be used to strengthen students' sense of empathy. Through direct experience experienced by students certainly has a considerable impact on students' understanding of historical events. Based on its kind, the living history itself is included in the experiential learning model where students can be directly involved as researchers with various research methods, either through inquiry or direct historical research methods, where the concept of learning through experience itself is not limited only to the active participation of students, students bring students to interpret the learning process and the meaning of the events studied. This can be seen from the opinion expressed by Daniel P O'neil (2016: 26) which states that living history on the implementation can provide a real experience to students by looking directly at historical places where it can help reflective thinking process in students, by seeing the evidence of the past and make it is connected to the life of the present [11]. In the implementation itself living history is not only a learning strategy based on the text, but more than that the implementation of living history can be done by performing demonstrations and continued in writing historical explanation in accordance with the learning experience that has been obtained by students.

Seeing from the exposure, the concept of living history is in accordance with the triangle of experience that has been described by Edgar Dale as follows:

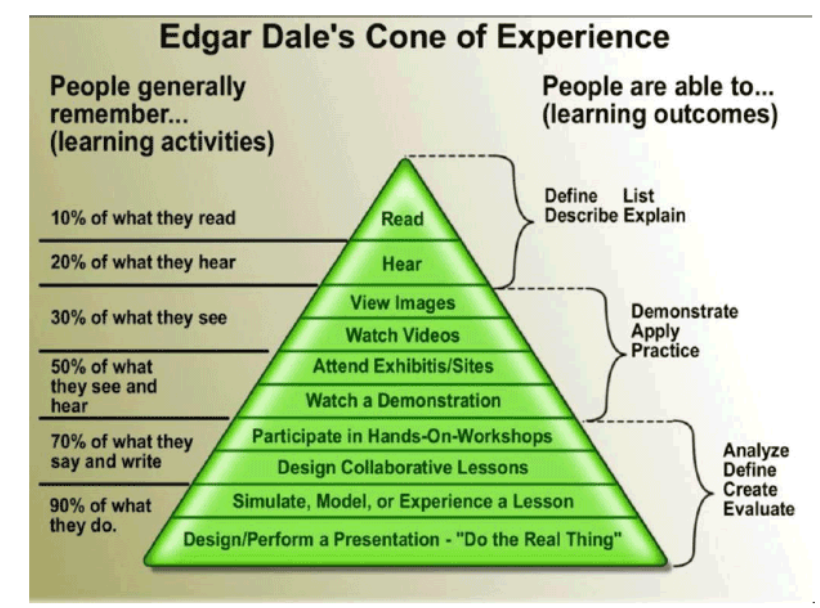

Figure 1: Concept of Living History

Source: Google

Through the picture of the effectiveness of learning contained on the conical experience of Edgar Dale it can be explained that, if the use of living history learning model on learning history can provide a big implication in the achievement of learning objectives of history which in this context is the history of learners since living history itself is a model of learning which can give students a direct learning experience by looking at existing historical heritage in a region can give the students a space that not only stimulates the cognitive but also hone the creativity of the students in analyzing the historical source which is displayed, more than that the use of living history itself can push the ability social students. Through the execution of living history in history learning can even undermine a partition of abstraction in history, this is because of the 
direct experience gained from students in the process of observation, source collection, data analysis, and explanation in the form of student reports [11].

Providing direct experience to students through visits to historical sites is one concept that can be used in the implementation of living history in class. Furthermore, in principle living history in history learning can also be performed by presenting reactors in historical events either in the form of docudrama or presenting them through visual representation of real models that describe the state of a historical event, which is used by Mark, L. Daniel (2010: 135) which carries the concept of meaningful learning through the depiction of historical figures who not only can create a cheerful atmosphere but also meaningful by encouraging students to reflective thinking. Through the strategy used by Mark, L. Daniel then continues the process by assigning an assignment to the students to observe the history that surrounds the learner's surroundings by borrowing the inquiry learning model. Through this assignment the students are trained to deal with the real community which aims to shape students' social skills.

Douglas Selwyn (2008) argues that Living History is ideal for use in social studies, especially in history because this model provides an ideal class picture with an active learning process and encourages students to experience a historical event with direct involvement in a process of observing and gathering information. Stimulate creativity for learners into the benefits of living history where the delivery of material can be done through simple direct observation, role play, audio visual display as reinforcement, train students in writing creative journals, even through music. With this, of course the implementation of living history into a model of learning is very suitable to answer the problem in learning history in Tabalong.

Living history learning model is expected to provide encouragement to learners to be more sensitive to the surrounding environment. It is also encouraged to develop discovery and inquiry process skills, such as observing, conducting interviews, selecting material / historical sources, classifying, finding something, even in generalizing. The model of living history also invites learners to conduct activities visit to historical places. The history, at least, has 3 aspects that are educational: recreational, inspirational, and educative. This model can also move the attitude and behavior that focused on the value of history, such as the value of love the homeland, willing to sacrifice, solidarity, and the spirit of unity.

Robert Douch (1967) stated that there are at least three ways to apply the living history model:

1. Linking the material with examples of local events so that learners get a more vivid picture of an event.

2. Browse or visit directly to historical sources and collect historical data in the school environment.

3. Conduct a special study of the historical aspects in the environment around the learner.

Based on the above exposure it can be said if this learning model is very suitable to use in learning history by raising local events and cultural wisdom that exist around the learners in a wide range of local imagery whether it concerns history, culture, and wisdom in a wide range so that participants students have the opportunity to learn to build and discover identity through an active, creative, effective, and fun learning process. 


\section{Living History to Improve Historical Empathy}

Seeing the state of the nation's young people who continue to show symptoms of antipathy to its history is a concern for all the elements involved in the world of education, especially historical education is the subject of the formation of the nation's personality with the form of good citizens. The problems that continue occurring cannot be separated from the apathy that indicated by the young generation of Indonesia especially the school-aged in paying attention to the history of the Indonesian nation. Not infrequently as has been described previously that history continues to be a lesson that is considered less important and boring when compared with the science lesson or language. Stereotype that attached inherent in the subjects history cannot be separated from the lack of strategy and the lack of meaning in the lesson of history.

The real problems of learning that occurred in Tabalong Regency refer to 1) the lack of involvement of learners during the learning process of history, 2) historical learning model that is less appropriate and cannot present a cheerful atmosphere, 3) conventional model that is still the main choice of learning history, 4 ) the integration of local history in the study of national history is still very minimal, 5) not yet developed the skills of historical thinking because it is still racing history facts, 6) the source of history is very minimal, and 7) not fully integrated the value of events and localization in learning history. Therefore it is not wrong if the stereotype of classic problems in the history of learning is still happened even it has an impact on the emergence of antipathy symptoms of history is now very easy to find.

Based on these problems it is necessary a model of learning that can be the best way out to be able to realize the history of student empathy. Students 'history of empathy can only be achieved through an understanding of events and reconstructions of historical perpetrators' perspectives that analysis by students in addition to providing direct experience to students by visually displaying historical sites or historical sources into one that can be used to strengthen the history of learners (Brooks , 2008: 2), so that based on the living history as an alternative model of learning in maximal use, not only to form students' understanding in the cognitive domain, but also affective and psychomotor students formed through the stage of applying and writing history as a result of observation reports learners.

Living history learning model that is sourced in the event around the student's residence can be done by using the inquiry learning model approach and the steps of historical research. Both concepts of this research model is very suitable with the purpose of learning history and object of observation of the student site or relic history. Inquiry itself is a learning model that involves the active participation of students who can develop attitudes and personality. The attitudes and personalities that develop with inquiry learn, among other things, doubt the old truth and want to know something new, appreciate reasoning as a way to gain the truth, value the data as a means to test the truth, objective to the existing data and avoid prejudice, willing to accept [15]. Obviously the concept is highly relevant to historical research steps that focus on source criticism, source interpretation or analysis, and explanation. 


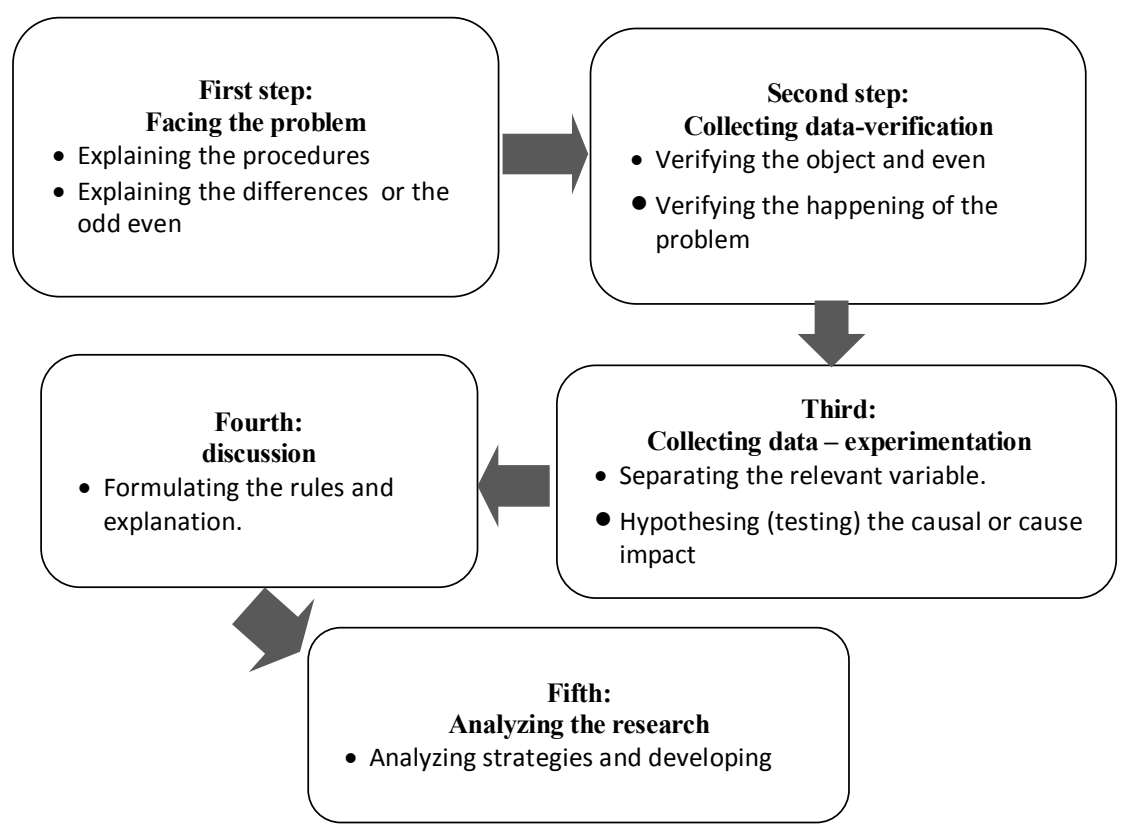

Figure 2. Scheme of Teaching Structure Research Exercise Model Source: Joyce, et al., 2011: 207

Through the application of living history learning, students experience direct experience that involves understanding thinking to the evaluation stage with the form of historical explanation report. Raising the material around the place of learners can directly affect the sensitivity of the social conditions of the community so that they can make a very useful provision for learners to jump directly socialize the community.

Discussing about the existing history of the environment around the student's residence is the object of study that is characteristic of living history, but what needs to be remembered here is that the living history as "train" with learners who are in it. This analogy is enough to show the special role of living history where by using this learning model students can see backward through the process of data collection, analyzing, until the writing phase and connect it with the real state of society today, which needs to be addressed wisely taking the meaning continues to exist in a historical event. Three historical concepts that we must always remember are human, space, and time are arranged chronologically, through the use of living history model learners are invited to discover and explore historical events that occur around the environment by collecting various sources through the source criticism stage, so that the interaction of historical sources and learners as researchers directly intertwined.

Living history is one of the models that can be used to guide learners in performing historical events in the environment where learners live their daily lives. Living History has a study of events or local history which then provides livelier lustration from the description of national historical events consisting of a collection of local events, by conducting exploration activities of the environment (visitation) as well as a case study in depth about the various aspects of history in the environment surrounding learners. Living history learning model is basically an implementation of historical research so that learners are able to review the history and write history through historical research 
techniques. Living history learning can be utilized to be able to break through the boundary between theory and reality, with direct sourced to the environment so students can directly explore the social conditions as society. The living history model as described previously is an adoption of historical research, so the steps that can be applied in the application of this learning model have at least three major stages to be followed: heuristic, criticism, and histography [17].

1. In the heuristic stage we are required to seek and find sources that are indeed relevant to the theme we examine.

2. Then after we find the sources, we enter into the next stage of source criticism which is the stage where the sources are filtered and tested the truth so that we really get the source of history that can be justified truth.

3. After completion of the criticism stage of the source, we go to the last stage of histography or the stage of history writing.

Living history that involves direct learners actively in the process of gathering information until the writing stage becomes one of the learning model that is very suitable if used to improve the empathy of learners history. Empathic history that emerges through the learners' understanding of historical events and the construction of perceptions made by learners against the perpetrators of history indirectly become one of the steps passed in the use of living history model in history learning. Quoting from Puspitasari (2016: 202) the application of living history to the learning of local history, can begin with the educator to determine the planning of a learning activity [18]. The first step is the history of making a plan that begins with the selection of historical topics that are considered interesting from the environment around the school. The second step is the educator forming groups`activities, the third step is each group, drawing up a work plan that contains various activities up to final report preparation. The next step is the implementation of activities directly on the environment.

Based on these steps it is hoped that it will be able to touch specifically on the understanding of historical events and the withdrawal of historical events as a medium of contextualization closely related to historical empathy in the opinion expressed by Barton and Levstik in (Brooks, 2011: 2) that historical empathy includes three important points of value absorption, attitude application, and perspective development that can teach students to appreciate different perceptions as part of social interaction. History's empathy can be said to be a reasonably difficult thinking ability to build, but based on the research that Brooks (2011: 2) has made, historical empathy can be built through cognitive stimuli and affective applications through the use of historical learning resources. So based on the application of living history model to show and involve students directly can be a choice of educators to achieve curricular goals of historical empathy as a result of learning history.

\section{CONCLUSION}

Historical empathy is the result of historical learning that can be formed through the process of cognitive stimuli through the understanding of historical events and affective applications through the reconstruction of the perceptions of the perpetrators of history, through both of them the historical empathy has three important points as its formers of values, attitudes, and understanding of history. In order to achieve the empathy of the student's history, it is required a proper learning model not only to 
stimulate students through conventional teaching and learning activities but also to develop students 'historical thinking skills by involving the attitude and movement aspects so that the living history model can be used as the educator's choice in improving students' history empathy. Living history as a learning model that comes from the environment around the learner with the concept of inquiry and historical research is very compatible with the 2013 curriculum that has been applied in Indonesia. Because this learning model is one of the most demanding models of active participation of students through the study of simple historical research by passing through the process of data collection, criticism, interpretation or analyzing and explanation. Through these four steps coupled with direct experience students are expected to form a perceptual and steady construct in historical understanding so that historical empathy can be achieved.

\section{REFERENCES}

[1] Kurniawan, M. D. (2017, Juni 13). Implementasi Model Pembelajaran Living History di Sekolah. Retrieved from http://ghinaya.blogspot.co.id/2009/09/implementasi-modelpembelajaran-living_04.htm

[2] Endacott, J \& John S. 2014.Historical empathy and pedagogical reasoning. The International Society for the Social Studies.dalam Jurnal Social Studies Research Vol. 39. (Online).

[3] Moleang, L.J. 2007. Metode Penelitian Kualitatif. Bandung: PT Remaja Rosdakarya.

[4] Aman. 2011. Model Evaluatif Pembelajaran Sejarah. Yogyakarta:Ombak.

[5] Gottschalk, L. 2006. Mengerti Sejarah. Terj. Nugroho Notosusanto. Jakarta: Penerbit Universitas Indonesia (UI-Press).

[6] Hassan, H. 2015. Pendidikan Sejarah dalam mempersiapkan Generasi Emas.Prosiding Seminar Nasional dan Pertemuan Asosiasi Pendidik dan Peneliti Sejarah : Pendidikan Sejarah untuk Menyiapkan Generasi Emas Indonesia 2050. Banjarmasin 27-28 November 2015. Program Studi Pendidikan Sejarah Universitas Lambung Mangkurat.

[7] Howe, D. 2015. Empati : Makna dan Pentingnya. Yogyakarta: Pustaka Belajar.

[8] Brooks, S. 2010. Displaying Historical Empathy: What Impact can a Writing Assignment Have? Journal of Social Studies and Research Practice. Vol. 3 No. 2. (Online).

[9] Jensen, J. 2011. Developing Historical Empathy through Debate. Dalam Jurnal Sosial Studies Research and Practice. Vol. 3 No. 1 Spring (Online).

[10] Yilmaz, K., \& Koca, F. 2012. A Qualitative Study on Historical Empathy: Examination of. Gaziantep Üniversitesi Sosyal Bilimler Dergisi. Vol. 3, 855-879. (Online).

[11] O'Neil, D. P. 2016. Experiencing History Where it Happened: Living History and Re-enactment as Public History Tools. Vermont History. Vol.84 No. 1. (Online).

[12] Daniel, M. L. 2010. A Living History Classroom Using Re-Enactment to Enhance Learning. Social Education Journal. Vol. 74 No. 3. (Online)

[13] Selwyn, D. 2008. Living History in the Classroom: Integrative ats activities for making social studies meaningful. : Prafrock Press (Online)

[14] Douch, R. 1970. "Local History", dalam New Movement in the Study and Teaching of History (M. Ballard ed.). London: Temple Smith.

[15] Beyer, B.K. 1979. Inquiry in the Social Studies Classroom: A. Strategy for Teaching. Columbus, OH: Charles E. Merril Publ.Co.

[16] Joyce, B., Weil, M.,\& Calhoun, E. 2011. Models of Teaching Model-Model Pengajaran. Yogyakarta: Penerbit Pustaka Pelajar.

[17] Sjamsuddin, H. 2012. Metodologi Sejarah.Yogyakarta: Penerbit Ombak

[18] Puspita, D. E. 2017. Rancangan Pengembangan Media Pembelajaran Portofolio sebagai Pendukung Living History dalam Pembelajaran Sejarah Lokal. Sejarah Lokal : Tantangan dan Masa Depan. Malang: Fakultas Ilmu Sosial Universitas Negeri Malang 